\title{
The following Presents to the Library have been received, for which the Society tenders its grateful thanks.
}

1. Abhandlungen aus dem Mathematischen Seminar der Hamburgischen Universität.

2. Acta Academiae Aboensis.

3. American Journal of Mathematics.

4. American Mathematical Monthly.

5. Anais da Faculdade de Sciências do Porto.

6. Annales de la Faculté des Sciences de Marseille.

7. Annales de la Faculté des Sciences de l'Université de Toulouse.

8. Annales de la Société Polonaise de Mathématique.

9. Annales Scientifiques de l'Université de Jassy.

10. Annali della R. Scuola Normale Superiore di Pisa.

11. Annals of Mathematics.

12 Arkiv für Matematik, Astronomi och Fysik.

13. Bollettino della Unione Matematica Italiana.

14. Bulletin of the American Mathematical Society.

15. Bulletin de Mathématiques et de Physique de l' École Polytechnique de Bucarest.

16. Bulletin of the Calcutta Mathematical Society.

17. Bulletin de la Société Mathématique de France.

18. Bulletin de la Société Physico-Mathématique de Kasan.

19. Bulletin de la Société Royale des Sciences de Liége.

20. Bulletin Mathématique de la Société Roumaine des Sciences.

21. Bulletin of the University of Kansas.

22. Bulletin scientifique de l'Université d'Etat de Kiev.

23. Communications de la Société Mathématique de Kharkow.

24. Duke Mathematical Journal.

25. Fundamenta . Mathematicae.

26. The Mathematical Gazette.

27. The Indian Physico-Mathematical Journal.

28. Jahresbericht der Deutschen Mathematiker-Vereinigung.

29. Japanese Journal of Mathematics.

30. Journal de l'Institut Mathématique de l'Académie des Sciences d'Ukraine.

31. Journal of the Faculty of Science, Hokkaido Imperial University.

32. Journal of the Faculty of Science, Imperial University of Tokyo.

33. Journal of Science of the Hiroshima University.

34. Journal of the Indian Mathematical Society.

35. Journal of Mathematics and Physics, Massachusetts Institute of Technology.

36. Matematisk Tidsskrift.

37. Mathematica (Bucarest).

38. Matematiceski Sbornik (Recueil Mathématique), Moscow.

39. Mémoires de la Société Royale des Sciences de Liége.

40. Memoirs of the Faculty of Science and Agriculture, Taihoku Imperial University.

41. Memoirs and Proceedings of the Manchester Literary and Philosophical Society.

42. Mitteilungen der Mathematischen Gesellschaft in Hamburg.

43. Monatshefte für Mathematik und Physik.

44. Nachrichten von der Gesellschaft der Wissenschaften zu Göttingen (Mathematisch. physikalische Klasse). 
45. Nachrichten von der Gesellschaft der Wissenschaften zu Göttingen (Geschäftliche Mitteilungen).

46. Nieuw Archief voor Wiskunde.

47. Nova Acta Regiae Societatis Scientiarum Upsaliensis.

48. Proceedings of the American Philosophical Society.

49. Proceedings of the Cambridge Philosophical Society.

50. Proceedings of the Leeds Philosophical and Literary Society.

51. Proceedings of the Isondon Mathematical Society.

52. Proceedings of the National Academy of Sciences.

53. Proceedings of the Nova Scotian Institute of Science.

54. Proceedings of the Physico-Mathematical Society of Japan.

55. Proceedings of the Royal Society of Edinburgh.

56. Publications Mathématiques de l'Uni versité de Belgrade.

57. Publications de la Faculté des Sciences de l'Université Masaryk.

58. Publications from the Massachusetts Institute of Technology.

59. Publications du laboratoire d'A stronomie et de Géodésie de l'Université de Louvain.

60. Publications de l'Institut de Mathématiques de l'Université de Strasbourg.

61. Rendiconti del Circolo Matematico di Palermo.

62. Rendiconti del Seminario delle Facoltà di Scienze della R. Università di Cagliari.

63. Rendiconti del Seminario Matematico e Fisico di Milano.

64. Rendiconti del Seminario Matematico della R. Università di Padova.

65. Rendiconti del Seminario Matematico della R. Università di Roma.

66. Science Reports of the Tôhoku Imperial University.

67. Sitzungsberichte der Bayerischen Akademie der Wissenschaften zu München (Mathematisch-Physikalische Klasse).

68. Sitzungsberichte der Akademie der Wissenschaften in Wien (Math.-Naturwiss. Klasse).

69. The Mathematics Student (Indian Mathematical Society).

70. Studia Mathematica.

71. The Tôhoku Mathematical Journal.

72. Transactions of the Actuarial Society of America.

73. Travaux de l'Institut Physico-Mathématique Stekloff:

74. Verhandlungen der Naturforschenden Gesellschaft in Basel.

75. Vierteljahrschrift der Naturforschenden Gesellschaft in Zïrich.

76. Warsaw Prace Matematyczno-Fizyczne.

77. Wiskundige Opgaven mit de Oplossingen (Amsterdam). 